Jurnal Tanah dan Sumberdaya Lahan Vol 8 No 2: 515-525, 2021

e-ISSN:2549-9793, doi: 10.21776/ub.jts1.2021.008.2.22

\title{
EVALUASI KESESUAIAN LAHAN UNTUK TANAMAN NANAS DI DAS MIKRO SUPITURUNG KECAMATAN PLOSOKLATEN KABUPATEN KEDIRI JAWA TIMUR
}

\section{Land Suitability Evaluation for Pineapple Plants in the Supiturung Micro Watershed, Plosoklaten District, Kediri Regency, East Java}

\author{
Sarah Nur Shabrina*, Mochtar Lutfi Rayes, Christanti Agustina \\ Jurusan Tanah, Fakultas Pertanian, Universitas Brawijaya Jl. Veteran No.1 Malang 65145 \\ *Penulis korepondensi: sarahnurshabrina@gmail.com
}

\begin{abstract}
Fruit plants in Kediri Regency are classified as having good economic potential, one of which is pineapple. Pineapple plants in Kediri Regency have differences in productivity in each sub-district. The results of interviews with local farmers indicated that the Supiturung Micro Watersheds in Plosoklaten District had low pineapple productivity and were not yet optimal. Therefore, this study aimed to determine the factors causing differences and less optimal productivity of pineapples in the Supiturung Micro Watersheds and analyze the land suitability assessment of pineapple plants in the region. This study used a survey method with a physiographic approach to 10 Land Map Units (LMU) and determined 20 observation points as representatives. Data analysis was performed through correlation and multiple regression tests with the stepwise method to determine the land characteristics that most significantly affected pineapple productivity. Modification of the suitability class and modification of the criteria was carried out utilizing boundary line analysis, with class boundaries according to FAO (1976), namely class S1 (80-100\%), S2 (60-80\%), S3 (40-60\%), and N $(<40 \%)$ of the potential productivity. The land suitability evaluation results of pineapple plants in the Supiturung Micro Watersheds were included in land suitability classes S2, S3, and N. Based on the stepwise method analysis, the texture is a significant characteristic affecting the productivity of pineapples $(p<0.05)$ with a correlation coefficient value of 0.838 . The modification of land suitability criteria with boundary line analysis resulted in changes in one land characteristic, namely soil texture $\mathrm{S} 2, \mathrm{~S} 3$, and N. Initially, the rough class included in the N class was changed to S2 level along with the slightly rough level.
\end{abstract}

Keywords : GIS, land suitability, pineapple plant, SPKL

\section{Pendahuluan}

Tanaman nanas (Ananas comosus (L) Merr) merupakan tanaman buah perenial atau selalu tersedia sepanjang tahun. Tanaman nanas merupakan salah satu buah unggulan yang memiliki potensi ekonomi tinggi di Indonesia. Ekspor buah terbesar di Indonesia adalah nanas sebagai konsumsi segar (Cahyono et al., 2014). Berdasarkan data Badan Pusat Statistik (2018), produksi nanas di Indonesia pada tahun 2018 sebesar 1.805.506 ton atau naik dari tahun sebelumnya (2017) 1.795 .986 ton. Provinsi penghasil nanas terbesar adalah Provinsi Lampung dengan produksi sebesar 622.881 ton $(34,50 \%)$ dari total produksi nasional. Provinsi yang memiliki produksi nanas terbesar berikutnya adalah Provinsi Jawa Tengah dengan produksi sebesar 202.823 ton (11,23\%), Jawa Barat dengan produksi sebesar 180.802 ton $(10,01 \%)$, Sumatera Utara dengan produksi sebesar 145.618 ton $(8,07 \%)$, Jawa Timur sebesar 139.234 ton $(7,71 \%)$, dan provinsi lainnya sebesar 514.148 ton $(28,48 \%)$. Kabupaten Kediri merupakan produsen nanas 


\section{Jurnal Tanah dan Sumberdaya Lahan Vol 8 No 2: 515-525, 2021 e-ISSN:2549-9793, doi: 10.21776/ub.jts1.2021.008.2.22}

terbesar di Jawa Timur. Pertanian tanaman buah-buahan di Kabupaten Kediri memiliki potensi ekonomi yang cukup baik. Menurut data Badan Pusat Statistik (2019) produksi nanas di Kabupaten Kediri mengalami peningkatan dari 36,38 ribu ton pada tahun 2017 menjadi sekitar 132 ribu ton pada tahun 2018. Peningkatan produksi yang tinggi pada tanaman nanas di Kabupaten Kediri ini disebabkan oleh adanya peningkatan luas panen dan adanya pengolahan lahan secara intensif yang dilakukan oleh petani untuk meningkatkan produksi tanaman nanas. Pengolahan lahan intensif pada awalnya dapat meningkatkan hasil panen petani, namun pengolahan lahan yang dilakukan terus menerus juga dapat mengakibatkan penurunan produktivitas (Rachman et al., 2004) secara tidak langsung dapat menyebabkan beragamnya kualitas lahan sehingga produktivitas lahan juga menjadi berbeda. Hal tersebut terlihat pada data produktivitas nanas yang berbeda pada setiap kecamatan di Kabupaten Kediri. Produktivitas nanas tertinggi terdapat di Kecamatan Ngancar pada lereng Gunung Kelud, sedangkan di kecamatan lain memiliki produktivitas lebih rendah.

DAS Mikro Supiturung Kecamatan Plosoklaten menjadi fokus dalam penelitian ini. Lokasi ini dipilih berdasarkan hasil survei lapangan dan wawancara dengan petani setempat yang menyatakan bahwa produktivitas nanas belum optimal di daerah tersebut. Varietas nanas yang ditanam di daerah tersebut adalah varietas Pasir Kelud (PK-1) dengan grade yang variatif dari grade $A$ hingga grade $\mathrm{D}$, dan memiliki bobot $\pm 1 \mathrm{~kg}$ pada grade $\mathrm{A}$. Produktivitas nanas di Kecamatan Plosoklaten berkisar antara 60.000-65.000 biji hektar-1 atau sama dengan $\pm 65 \mathrm{t} \mathrm{ha}^{-1}$, yang mana seharusnya pada varietas PK-1 memiliki tingkat produktivitas tinggi yaitu 80-100 t ha-1 . Untuk mengetahui faktor yang menjadi penyebab perbedaan dan kurang optimalnya produktivitas nanas pada tiap wilayah di Kabupaten Kediri, perlu dilakukan penilaian kesesuaian lahan tanaman nanas di wilayah tersebut. Penilaian kesesuaian lahan diperlukan guna mendapatkan informasi mengenai kualitas dan karakteristik lahan yang sesuai sehingga dapat menentukan tingkat pengelolaan yang diperlukan. Berdasarkan uraian tersebut, maka perlu dilakukan suatu upaya untuk meningkatkan produktivitas dan pengembangan tanaman nanas pada setiap wilayah yang masih belum optimal di DAS Mikro Supiturung Kecamatan Plosoklaten Kabupaten Kediri Jawa Timur.

\section{Bahan dan Metode}

\section{Tempat dan waktu penelitian}

Penelitian dilakukan di DAS Mikro Supiturung Kecamatan Plosoklaten yang terletak di lereng barat Gunung Kelud, Kabupaten Kediri Jawa Timur (Gambar 1). Analisis SIG dilakukan di Laboratorium Pedologi dan Sistem Informasi Sumberdaya Lahan Jurusan Tanah Fakultas Pertanian Universitas Brawijaya Malang. Analisis sifat fisika tanah dilakukan di Laboratorium Fisika Tanah Jurusan Tanah, Fakultas Pertanian, Universitas Brawijaya, Malang. Analisis sifat kimia tanah dilakukan di Laboratorium Tanah Balai Pengkajian Teknologi Pertanian Jawa Timur.

\section{Alat dan bahan}

Alat yang digunakan dalam kegiatan penelitian ini meliputi software ArcGIS 10.3, software SPKL Versi 2.0, software SPSS 23, software Microsoft office 2016, GPS (Global Position System), avenza, Survei set, peralatan analisis laboratorium, alat tulis, kamera, dan laptop. Bahan penunjang penelitian ini berupa Peta Rupa Bumi Indonesia lembar Ngancar skala 1:25.000, Peta Rupa Bumi Indonesia lembar Kediri skala 1:25.000 (Bakosurtanal, 2010), DEMNAS resolusi 0.27 arc-second ( $8 \mathrm{~m})$, Peta Geologi lembar Kediri skala 1:100.000, Citra Google Earth wilayah Kediri tanggal perekaman April 2020, plastik, kertas label, dan sampel tanah.

\section{Rancangan penelitian}

Metode yang digunakan dalam melaksanakan penelitian yaitu dengan metode survei secara fisiografi untuk pengambilan data karakteristik (morfologi dan fisiografi) lahan dengan tingkat survei semi detail (skala 1:25.000) berdasarkan perbedaan Satuan Peta Lahan. Satuan Peta Lahan disusun dari hasil overlay shapefile penggunaan lahan, lereng dan geologi kemudian didapatkan 10 Satuan Peta Lahan. Setiap Satuan Peta Lahan yang berbeda dipilih dua titik pengamatan sebagai pewakil sehingga terdapat 20 titik pengamatan. 


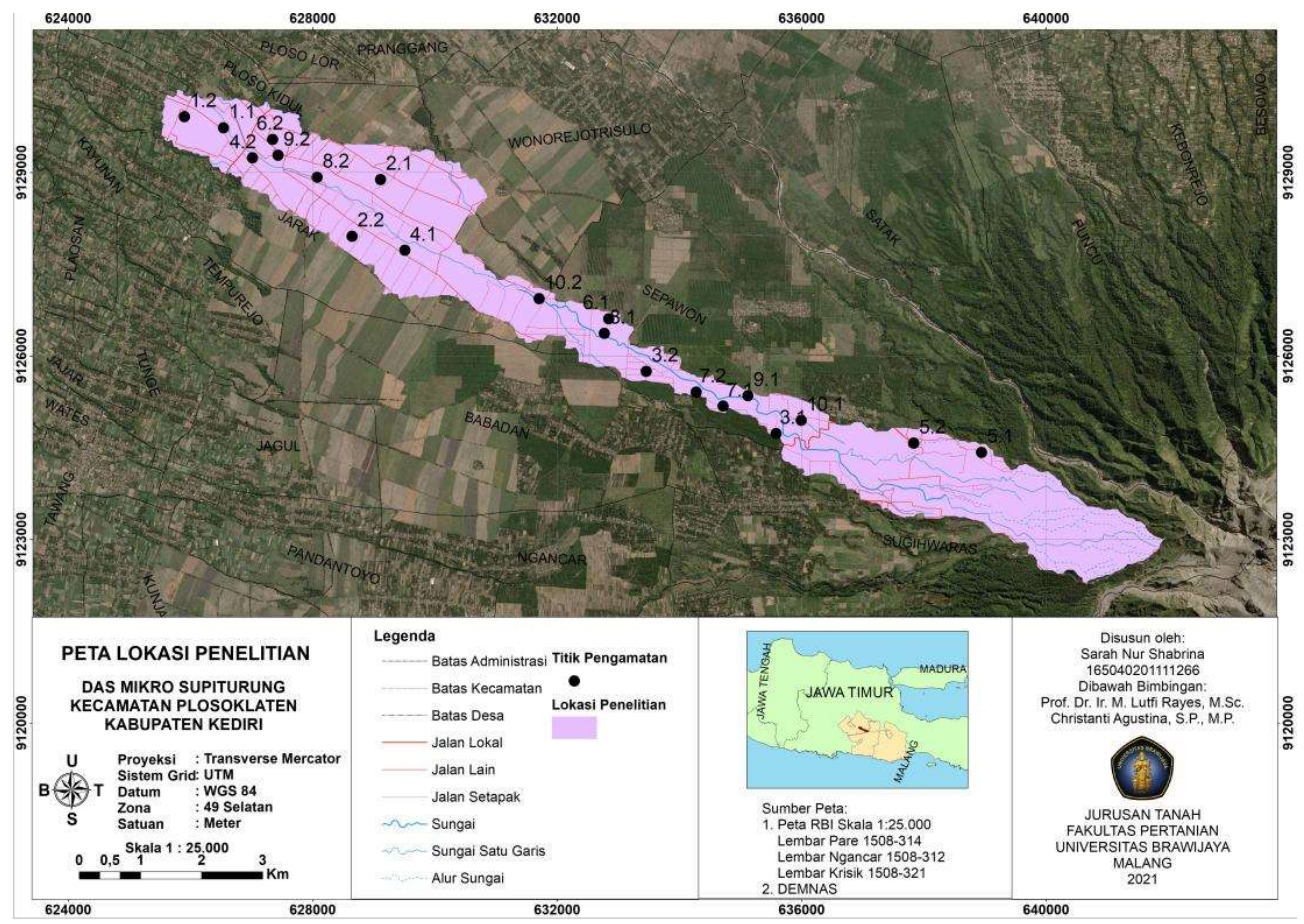

Gambar 1. Peta lokasi penelitian.

Tahapan penelitian dibagi menjadi tujuh tahapan yaitu persiapan, prasurvei, pembuatan peta, observasi lapangan, analisis laboratorium, dan pengolahan data.

\section{Pembuatan peta}

Peta dibuat sebagai penunjang kegiatan penelitian. Beberapa peta yang dibuat antara lain adalah peta lokasi penelitian, peta administrasi, peta lereng, peta beda tinggi, peta geologi, peta landform, peta penggunaan lahan, dan Satuan peta lahan di DAS Mikro Supiturung. Peta Satuan Penggunaan Lahan (SPL) dibuat untuk menunjukkan keragaman suatu wilayah dengan cara overlay shapefile penggunaan lahan, formasi geologi, serta persentase kelas kelerengan (Wahyunto et al., 2016). Selanjutnya, diberikan nomor SPL dan warna untuk menunjukkan perbedaan karakteristik disetiap SPL. Hasil overlay terdapat 10 SPL yang nantinya dijadikan acuan lokasi pengambilan sampel tanah untuk dianalisis di laboratorium.

\section{Observasi lapangan}

Pengamatan saat observasi lapangan dilakukan secara fisiografi dan morfologi merujuk pada petunjuk teknis pengamatan tanah oleh Balai Penelitian Tanah (2004). Pengamatan fisiografi bertujuan untuk validasi data yang telah didapatkan dengan kondisi aktual di lapangan. Kemudian pada pengamatan morfologi yaitu pembuatan minipit, pengeboran dan pengambilan sampel tanah. Pembuatan minipit $(50 \times 50 \mathrm{~cm})$ berfungsi untuk mendapatkan data sifat-sifat morfologi horizon penciri dan untuk mengetahui penyebaran variasi sifat-sifat tanah pada suatu daerah yang dipetakan. Kemudian dilanjutkan dengan pemboran sampai terdapat kontak untuk melengkapi deskripsi lapisan yang lebih dalam $(>50 \mathrm{~cm})$. Pemboran dilakukan untuk pengambilan sampel tanah terganggu sebagai sampel untuk analisis sifat fisika dan kimia tanah di Laboratorium.

\section{Analisis laboratorium}

Analisis dilakukan di Laboratorium Fisika Tanah Jurusan Tanah Fakultas Pertanian Universitas Brawijaya untuk analisis Fisika dan analisis kimia dilakukan di Laboratorium Tanah Balai Pengkajian Teknologi Pertanian Jawa Timur. Parameter dan metode analisis dapat dilihat pada Tabel 1. 
Tabel 1. Metode analisis laboratorium.

\begin{tabular}{lcc}
\hline Jenis Analisis & Satuan & Metode \\
\hline Tekstur Tanah & $\%$ & Pipet \\
Kapasitas Tukar Kation (KTK) & $\mathrm{cmol} \mathrm{kg-1}^{-1}$ & $\mathrm{NH}_{4}-\mathrm{Ac} 1 \mathrm{M}, \mathrm{pH} 7+\mathrm{NaCl} \mathrm{10 \%}$; Titrimetri \\
Kejenuhan Basa (KB) & $\%$ & \\
$\mathrm{pH}\left(\mathrm{H}_{2} \mathrm{O}\right)$ & - & Electrode Glass 1:1 \\
$\mathrm{C}$ - Organik & $\%$ & Walkley \& Black \\
Nitrogen - total & $\%$ & Kjeldahl; \\
& & Titrimetri \\
$\mathrm{P}_{2} \mathrm{O}_{5}$ & $\mathrm{ppm}$ & Olsen:Spektrofotometer \\
$\mathrm{Kdd}$ & $\mathrm{cmol} \mathrm{kg-1}$ & $\mathrm{NH}_{4}-\mathrm{Ac}$ 1 M, pH 7; AAS \\
\hline
\end{tabular}

\section{Analisis data}

Proses analisis data mencakup interpretasi data untuk klasifikasi tanah, kesesuaian lahan aktual, analisis karakteristik lahan yang signifikan memengaruhi produktivitas nanas, menentukan kelas kesesuaian aktual produktivitas nanas, dan modifikasi kriteria kesesuaian lahan tanaman nanas. Klasifikasi kesesuaian lahan mengacu pada Kunci Taksonomi Tanah (Soil Survey Staff, 2014). Klasifikasi kesesuaian lahan mengacu pada metode pencocokan (matching) antara karakteristik lahan dengan kriteria kesesuaian lahan. Penentuan kesesuaian lahan dilakukan menggunakan perangkat lunak SPKL versi 2.0. Kriteria kesesuaian lahan yang dijadikan dasar pencocokan adalah kriteria acuan (Ritung et al., 2011) dan kriteria hasil modifikasi berdasarkan analisis boundary line. Karakteristik lahan yang paling mempengaruhi produktivitas nanas ditentukan dengan metode regresi berganda yaitu analisis stepwise menggunakan SPSS versi 23. Kelas produktivitas nanas ditentukan berdasarkan pengelompokkan nilai produksi tanaman yang mengacu pada FAO (1976). Modifikasi kriteria kesesuaian lahan tanaman nanas menggunakan boundary line analysis dengan memberikan garis batas pada diagram yang menunjukkan hubungan antara produksi dengan karakteristik lahan.

\section{Hasil dan Pembahasan}

\section{Kondisi umum wilayah}

Secara astronomis, daerah penelitian berada pada 9.123 .000 - 9.132.000 m S dan $624.000-$ $640.000 \mathrm{~m}$ E dengan sistem proyeksi Universal Transverse Mercator pada Zona 49 Selatan.
Secara geografis wilayah penelitian berada pada lereng barat Gunung Kelud dengan batas wilayahnya sebelah barat adalah Kecamatan Pare dan Gurah, sebelah utara Kecamatan Puncu, sebelah timur Gunung Kelud serta sebelah selatan Kecamatan Wates.

\section{Satuan peta lahan}

Berdasarkan hasil survei lapangan dan analisis data yang telah dilakukan serta hasil proses overlay shapefile penggunaan lahan, lereng dan geologi menggunakan software ArcGIS kemudian didigitasi berdasarkan garis batas ketiga atribut tersebut, didapatkan Satuan Peta Lahan yang dikategorikan menjadi sepuluh Satuan Peta Lahan (SPL). Kesepuluh Satuan Peta Lahan tersebut terdiri atas tiga sublandform yaitu sublandform lereng vulkan bawah (Vab 1.1.5), sublandform aliran lahar (Vab 1.2), dan sublandform lungur vulkan (Vab 1.6) (Marsoedi et al., 1997). Peta Satuan Peta Lahan dapat dilihat pada Gambar 2.

\section{Satuan peta tanah}

Hasil survei menunjukkan terdapat 7 jenis tanah di lokasi penelitian. Antara lain Typic Hummudepts, Entic Hummudepts, Typic Eutrudepts, Typic Udipsamments, Arenic Eutrudepts, Typic Dystrudepts, dan Typic Udorthents. Satuan Tanah tersebut masuk kedalam 10 Satuan Peta Lahan (SPL) sehingga didapatkan 10 Satuan Peta Tanah (SPT).

\section{Karakteristik lokasi penelitian}

Data iklim di lokasi penelitian diperoleh dari Badan Pusat Statistik Kabupaten Kediri, dengan pengukuran yang dilakukan oleh Dinas Pertanian dan Perkebunan Kabupaten Kediri. 


\section{Jurnal Tanah dan Sumberdaya Lahan Vol 8 No 2: 515-525, 2021 e-ISSN:2549-9793, doi: 10.21776/ub.jts1.2021.008.2.22}

Data yang digunakan merupakan iklim yang terjadi pada sepuluh tahun terakhir (20112020). Data iklim kemudian diolah dengan menggunakan aplikasi Java Newhall Simulation Model (JNSM) untuk menentukan rejim kelembaban dan rejim suhu tanah pada titik pengamatan. Rejim kelembapan tanah pada lokasi penelitian termasuk kedalam kategori udik, hal ini dicirikan oleh kondisi tanah yang tidak kering kumulatif selama 90 hari pada penampang kontrol di kedalaman $10-30 \mathrm{~cm}$ dari permukaan tanah (Soil Survey Staff, 2014). Rejim suhu tanah di lokasi penelitian termasuk dalam kategori isohipertermik yang mana di tiap titik pengamatan rata-rata suhu tahunannya bernilai $>22^{\circ} \mathrm{C}$.

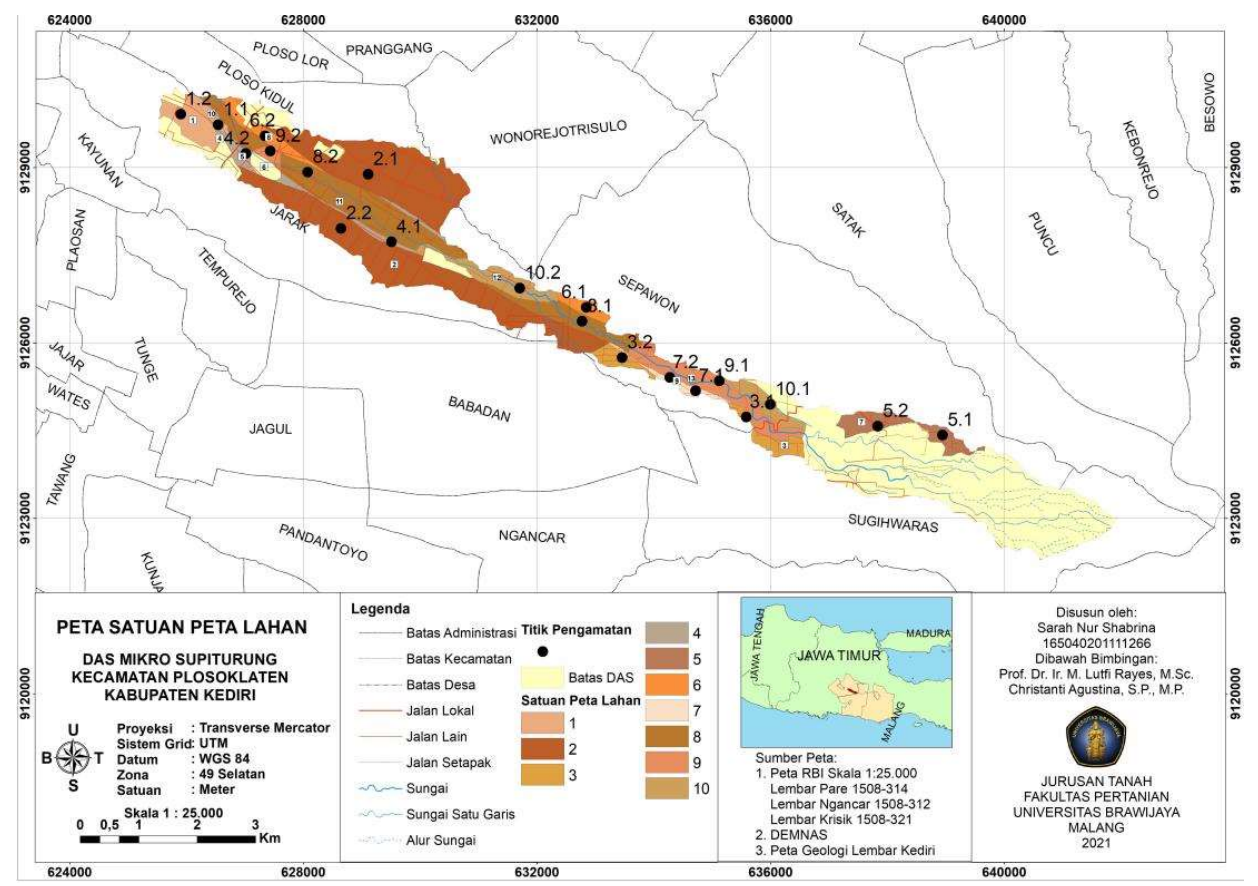

Gambar 2. Peta satuan peta lahan.

\section{Ketersediaan air (wa)}

Curah hujan rata-rata diperoleh dari Badan Pusat Statistik Kabupaten Kediri, dengan pengukuran yang dilakukan oleh Dinas Pertanian dan Perkebunan Kabupaten Kediri pada tahun 2011-2020 menghasilkan rerata curah hujan sebesar 1797,5 mm tahun ${ }^{-1}$ sehingga termasuk ke dalam kelas kesesuaian S2.Curah hujan memegang peranan pertumbuhan dan produksi tanaman. Hal ini disebabkan air sebagai pengangkut unsur hara dari tanah ke akar dan dilanjutkan ke bagian - bagian lainnya (Tjasyono et al., 2004).

\section{Ketersediaan oksigen (oa)}

Ketersediaan oksigen dalam tanah dipengaruhi oleh kondisi drainase tanah tersebut. Menurut Ritung et al. (2011) Drainase dapat dikatakan baik apabila tanah memiliki konduktivitas hidrolik sedang dan daya menahan air sedang, lembab, tapi tidak cukup basah dekat permukaan. Kondisi drainase di lokasi penelitian dominan termasuk kedalam kelas kesesuaian S1.

\section{Media perakaran (rc)}

Berdasarkan hasil analisis segitiga tekstur, didapatkan empat kelas tekstur di lokasi penelitian yaitu lempung berdebu, lempung berpasir, pasir berlempung, dan pasir. Tekstur di lokasi penelitian berdasarkan acuan kelas kesesuaian Ritung et al. (2011) masuk kedalam tiga kelas kesesuaian lahan yaitu S1, S2, dan N. Berdasarkan hasil analisis segitiga tekstur, didapatkan empat kelas tekstur yaitu lempung berdebu, lempung berpasir, pasir berlempung, dan pasir. Tekstur lempung berdebu terletak di 


\section{Jurnal Tanah dan Sumberdaya Lahan Vol 8 No 2: 515-525, 2021 e-ISSN:2549-9793, doi: 10.21776/ub.jts1.2021.008.2.22}

SPT 5 (Typic Dystrudepts). Selanjutnya untuk tekstur lempung berpasir tersebar di SPT 1, 2, 3 (Typic Eutrudepts), 6 (Typic Dystrudepts), 7,8 (Typic Udipsamments), 9.2 dan 10 (Entic Hummudepts). Kemudian untuk tekstur pasir berlempung tersebar di SPT 3 (Typic Hummudepts), 4, 5 (Typic Dystrudepts), 9.1, dan 10 (Typic Udorthents). Terakhir adalah tekstur Pasir yang terletak di SPT 5 (Arenic Eutrudepts) dan 8 (Typic Udorthents). Kedalaman tanah di lokasi penelitian berada pada rentang $27 \mathrm{~cm}$ hingga $80 \mathrm{~cm}$ dengan kelas kesesuaian dari S1-S3. Kedalaman tanah ditentukan berdasarkan batas perakaran yang terdapat di minipit.

\section{Retensi hara (nr)}

Kualitas retensi hara dapat diketahui dengan 4 karakteristik, yaitu KTK tanah, kejenuhan basa, $\mathrm{pH} \mathrm{H}_{2} \mathrm{O}$, dan C-Organik. Kapasitas Tukar Kation (KTK) Tanah disetiap Satuan Peta Tanah memiliki nilai berkisar antara 4,82-19,75 cmol kg-1. Berdasarkan acuan kelas kesesuaian Ritung et al. (2011) KTK di lokasi penelitian dominan kedalam kelas kesesuaian S2 (Cukup Sesuai) yaitu $5-16 \mathrm{cmol} \mathrm{kg}^{-1}$. Terdapat satu kelas kesesuaian S1 yaitu pada SPT 1.1. Kemudian pada SPT 1.2 hingga 10 termasuk kelas S2. Kejenuhan Basa disetiap Satuan Peta Tanah memiliki nilai berkisar antara 16-89\%. Menurut Syekhfani (2005), kejenuhan basa menunjukkan jumlah kation basa dalam persen yang terjerap dalam tanah. Semakin tinggi persentase kejenuhan basa maka semakin tinggi pula jumlah kation-kation basa yang tersedia bagi tanaman. Kejenuhan basa di lokasi penelitian berdasarkan acuan kelas kesesuaian Ritung et al. (2011) dominan kedalam kelas kesesuaian S1 (sangat sesuai) yaitu pada SPT 1.2, 2., 4.2, 5, 6, 7.1, 8, 9, dan 10. Pada SPT 1.1, 3, dan 7.2 termasuk kelas S2 (cukup sesuai) dan pada SPT 4.1 termasuk kelas S3 (sesuai marjinal). Tingkat kemasaman tanah di tiap lokasi pengamatan termasuk kedalam kategori sangat masam-agak alkalis dengan $\mathrm{pH} 4,3$ hingga 7,7. Kadar $\mathrm{C}$ organik di tiap lokasi pengamatan termasuk dalam kategori sangat rendah-sedang berada pada rentang kadar 0,41-2,25\% dengan kelas kesesuaian S1S3.

\section{Hara tersedia (na)}

Kualitas hara tersedia dapat diketahui dengan 3 karakteristik, yaitu Fosfor tersedia $\left(\mathrm{P}_{2} \mathrm{O}_{5}\right)$, Total Nitrogen ( $\mathrm{N}$ total), dan Kalium dapatdipertukar (Kdd). Kandungan P tersedia dalam tanah dihitung berdasarkan kandungan $\mathrm{P}_{2} \mathrm{O}_{5}$ tanah. $\mathrm{P}$ tersedia di lokasi penelitian termasuk dalam kategori sangat rendah - sedang yaitu pada rentang 0,9-42,7 $\mathrm{mg} 10 \mathrm{0g}^{-1}$ dengan kelas kesesuaian S1-S3. Selanjutnya untuk persentase total nitrogen $(\mathrm{N}$ total) tanah di lokasi penelitian termasuk dalam kategori sangat rendah - sedang yaitu pada rentang $0,01-0,42 \%$ dengan kelas kesesuaian S1-S3. Kemudian yang terakhir kalium dapat-dipertukar di lokasi penelitian termasuk dalam kategori sangat rendah - sangat tinggi yaitu pada rentang $0,06-2,73 \mathrm{cmol} \mathrm{kg}^{-1}$ dengan kelas kesesuaian lahan S1-N.

\section{Bahaya erosi (eh)}

Tingkat bahaya erosi dapat dinilai berdasarkan kelas bahaya erosi aktual dan kelerengan lahan.Terdapat lima kategori bahaya erosi menurut Ritung et al. (2011) yaitu sangat ringan, ringan, sedang, berat, dan sangat berat. Pada lokasi penelitian terdapat tiga kategori yaitu kelas bahaya erosi ringan, sedang, dan berat. Kelas bahaya erosi di lokasi penelitian di dominasi oleh kelas ringan (S2) di semua satuan tanah kecuali pada SPT 8 (Typic Udorthents) yang memiliki kelas berat (S3).

\section{Kesesuaian lahan aktual tanaman nanas}

Berdasarkan hasil analisis karakteristik dan kualitas lahan secara keseluruhan yang dilakukan di DAS Mikro Supiturung Kecamatan Plosoklaten Kabupaten Kediri, didapatkan kelas kesesuaian lahan aktual yang mengacu pada kriteria (Ritung et al., 2011; BBSDLP, 2011) termasuk kedalam kelas S2 (cukup sesuai), S3 (sesuai marjinal) dan $\mathrm{N}$ (tidak sesuai) (Tabel 2). Secara umum, sebagian besar Satuan Peta Tanah memiliki kelas kesesuaian N. Pada setiap SPT memiliki kelas kesesuaian dan faktor pembatas yang berbeda-beda. Peta Kelas Kesesuaian Lahan Lokasi Penelitian Menurut Kriteria Acuan Ritung et al. (2011) dapat dilihat pada Gambar 3. 
Jurnal Tanah dan Sumberdaya Lahan Vol 8 No 2: 515-525, 2021

e-ISSN:2549-9793, doi: 10.21776/ub.jts1.2021.008.2.22

Tabel 2. Kesesuaian lahan aktual tanaman nanas di lokasi penelitian.

\begin{tabular}{|c|c|c|c|}
\hline No.SPT & Taksa Tanah & SubKKL & Faktor Pembatas \\
\hline \multirow{3}{*}{1} & Typic Hummudepts & $\mathrm{S} 3 \mathrm{rc} / \mathrm{nr} / \mathrm{na}$ & Kedalaman tanah, $\mathrm{pH}$ aktual, $\mathrm{P}$ tersedia \\
\hline & Typic Hummudepts & S3 na & P tersedia \\
\hline & Asosiasi & & \\
\hline \multirow[t]{3}{*}{2} & Entic Hummudepts & S3 na & Kdd \\
\hline & Typic Hummudepts & $\mathrm{N}$ na & Kdd \\
\hline & Kompleks & & \\
\hline \multirow[t]{2}{*}{3} & Typic Eutrudepts & S3 na & P-tersedia \\
\hline & Typic Hummudepts & $\mathrm{N} \mathrm{rc}$ & Tekstur \\
\hline \multirow{3}{*}{4} & Typic Udipsamments & $\mathrm{N} \mathrm{rc}$ & Tekstur \\
\hline & Typic Udipsamments & $\mathrm{N}$ rc & Tekstur \\
\hline & Asosiasi & & \\
\hline \multirow[t]{4}{*}{5} & Arenic Eutrudepts & $\mathrm{N} \mathrm{rc}$ & Tekstur \\
\hline & Typic Dystrudepts & $\mathrm{N} \mathrm{rc}$ & Tekstur \\
\hline & Kompleks & & \\
\hline & Typic Hummudepts & $\mathrm{S} 3 \mathrm{rc} / \mathrm{na}$ & Kedalaman tanah, $\mathrm{P}$ tersedia \\
\hline 6 & Typic Dystrudepts & $\begin{array}{l}\mathrm{S} 2 \mathrm{wa} / \mathrm{oa} / \mathrm{rc} / \\
\mathrm{nr} / \mathrm{na} / \mathrm{eh}\end{array}$ & $\begin{array}{l}\text { Curah hujan, drainase, tekstur, kedalaman } \\
\text { tanah, KTK, pH aktual, N total, P } \\
\text { tersedia Bahava erosi }\end{array}$ \\
\hline \multirow{2}{*}{7} & Typic Dystrudepts & $\mathrm{S} 3 \mathrm{rc} / \mathrm{na}$ & Kedalaman tanah, $\mathrm{P}$ tersedia \\
\hline & $\begin{array}{l}\text { Typic Dystrudepts } \\
\text { Kompleks }\end{array}$ & $\mathrm{S} 3 \mathrm{rc} / \mathrm{na}$ & Kedalaman tanah, $\mathrm{P}$ tersedia, Kdd \\
\hline \multirow[t]{2}{*}{8} & Typic Udipsamments & $\mathrm{S} 3 / \mathrm{rc} / \mathrm{nr} / \mathrm{na}$ & $\begin{array}{l}\text { Drainase, kedalaman tanah, C-Organik, } \mathrm{P} \\
\text { tersedia }\end{array}$ \\
\hline & Typic Udorthents & $\mathrm{N} \mathrm{rc}$ & Tekstur \\
\hline \multirow{3}{*}{9} & Typic Udorthents & $\mathrm{N} \mathrm{rc}$ & Tekstur \\
\hline & Typic Udorthents & $\mathrm{N}$ na & Kdd \\
\hline & Asosiasi & & \\
\hline \multirow[t]{2}{*}{10} & Typic Udorthents & $\mathrm{N} \mathrm{rc}$ & Tekstur \\
\hline & Entic Hummudepts & $\mathrm{S} 3 \mathrm{rc} / \mathrm{na} / \mathrm{eh}$ & Kedalaman tanah. P-tersedia, Lereng \\
\hline
\end{tabular}

Keterangan: SPT: Satuan Peta Tanah; SubKKL: Sub Kelas Kesesuaian Lahan; Acuan kriteria dari Ritung et al. (2011).

Produktivitas aktual dan kelas kesesuaian lahan menurut produktivitas aktual nanas

Produktivitas tanaman nanas di lokasi penelitian berkisar antara 60,5-64,9 $\mathrm{t} \mathrm{ha}^{-1}$. Produktivitas terendah sebesar $60,5 \mathrm{t} \mathrm{ha}^{-1}$ yaitu pada SPT 5.2 dengan jenis tanah Typic Dystrudepts. Produktivitas tertinggi sebesar $64,9 \mathrm{t} \mathrm{ha}^{-1}$ yaitu pada SPT 6.1 dengan jenis tanah Typic Hummudepts. Di lokasi penelitian terdapat enam titik yang termasuk dalam penggunaan lahan tegalan dengan komoditas nanas yaitu pada SPT 5.2, 6.1, 7.1, 8.1, 9.1, dan 10.2. Produktivitas nanas pada lokasi penelitian memiliki nilai persentase pada rentang 71,18 $76,35 \%$. Nilai persentase produksi ini didapat berdasarkan hasil perhitungan nilai produksi aktual nanas pada setiap titik pengamatan dibagi dengan potensi produksi nanas $\left(85 \mathrm{t} \mathrm{ha}^{-1}\right)$ kemudian dikalikan 100\%. Menurut FAO (1976), tingkat produktivitas $80-100 \%$ termasuk kelas sangat sesuai (S1), 60-80\% termasuk kelas cukup sesuai (S2), 40-60\% termasuk kelas sesuai marjinal (S3), dan $<40 \%$ termasuk kelas tidak sesuai $(\mathrm{N})$.

\section{Modifikasi kriteria dan kelas kesesuaian lahan}

Modifikasi kriteria kesesuaian lahan dilakukan pada karakteristik-karakteristik lahan yang berpengaruh signifikan terhadap produktivitas nanas dan diketahui melalui analisis stepwise. Modifikasi kriteria dilakukan dengan boundary line analysis. 


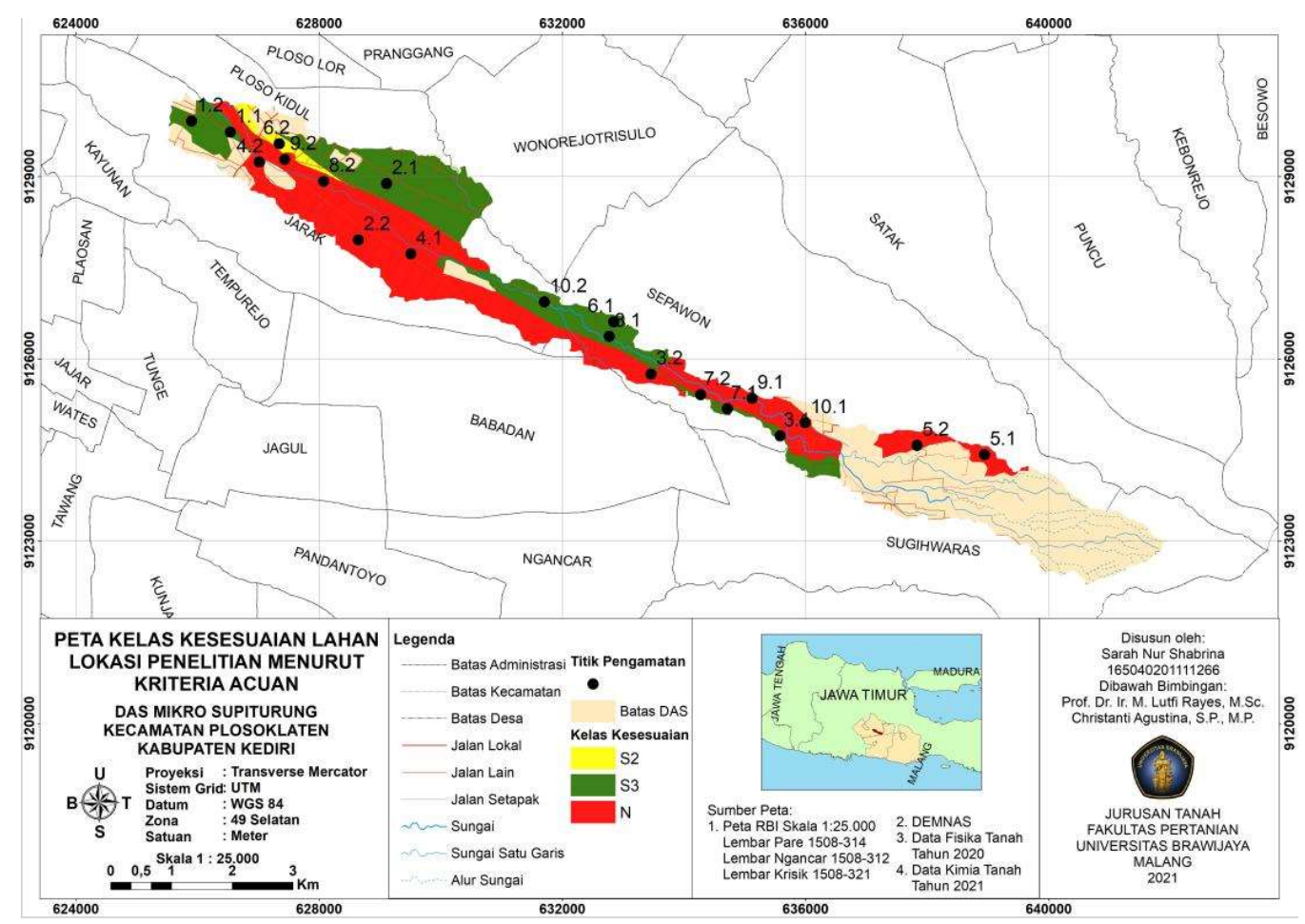

Gambar 3. Peta kelas kesesuaian lahan lokasi penelitian menurut kriteria acuan Ritung et al. (2011).

\section{Karakteristik lahan yang mempengaruhi produktivitas nanas}

Hasil analisis korelasi dan regresi dengan menggunakan software SPSS versi 23.0 menunjukkan hasil bahwa dari setiap karakteristik tanah yang dianalisis yaitu pada ketersediaan air (curah hujan), ketersediaan oksigen (drainase), media perakaran (tekstur, dan kedalaman tanah), retensi hara (KTK tanah, pH aktual, dan C oOrganik), hara tersedia (NTttal, P tersedia, dan Kdd), serta bahaya erosi (lereng, dan bahaya erosi), terdapat satu karakteristik lahan yang berpengaruh signifikan terhadap produktivitas tanaman nanas di lokasi penelitian yaitu tekstur tanah. Tanah-tanah di lokasi penelitian dominan bertekstur pasir dan termasuk dalam kelas kesesuaian N. Tanah bertekstur pasir mempunyai luas permukaan yang kecil sehingga sulit menyerap (menahan) air dan unsur hara. Rosyidah dan Wirosoedarmo (2013), menyatakan bahwa tanah yang bertekstur kasar (pasir) mempunyai kemampuan menahan air yang kecil dari pada tanah bertekstur halus. Air dibutuhkan sebagai pengangkut unsur hara dari tanah ke akar dan dilanjutkan ke bagian - bagian lainnya (Tjasyono et al., 2004). Tekstur tanah merupakan karakteristik lahan yang berpengaruh signifikan terhadap produktivitas nanas $(\mathrm{p}<0.05)$, dengan nilai koefisien korelasi 0.838 (Tabel 3). Berdasarkan analisis regresi, kedua variabel ini dapat digambarkan dengan persamaan linier $\mathrm{y}=$ $1,350 \mathrm{x}+58,933$ dengan $\mathrm{R}^{2}=0,701$. Hal ini menunjukkan bahwa tekstur tanah memberikan pengaruh sebesar $70,1 \%$ terhadap produktivitas nanas di lokasi penelitian, dan sisanya yaitu merupakan faktor lain. Berdasarkan nilai korelasi, menunjukkan bahwa tekstur dan produktivitas tanaman nanas memiliki hubungan yang positif (berbanding lurus). Gambar 4. menunjukkan bahwa produktivitas nanas akan meningkat seiring peningkatan karakteristik tekstur tanah. Penentuan skor tekstur tanah berdasarkan buku petunjuk pengoperasian SPKL Versi 2.0. 
Jurnal Tanah dan Sumberdaya Lahan Vol 8 No 2: 515-525, 2021

e-ISSN:2549-9793, doi: 10.21776/ub.jts1.2021.008.2.22

Tabel 3. Pearson Correlation

\begin{tabular}{llc|c}
\hline Correlations & & Produktivitas & Tekstur \\
\hline Produktivitas & Pearson Correlation & 1 & $.838^{*}$ \\
\cline { 2 - 4 } & Sig. (2-tailed) & \multicolumn{1}{c}{} & .037 \\
\cline { 2 - 4 } & $\mathrm{N}$ & $.838^{*}$ & 6 \\
\hline \multirow{2}{*}{ Tekstur } & Pearson Correlation & .037 & 1 \\
\cline { 2 - 4 } & Sig. (2-tailed) & 6 & 6 \\
\cline { 2 - 4 } & $\mathrm{N}$ & & \\
\hline
\end{tabular}

*. Correlation is significant at the 0.05 level (2-tailed).

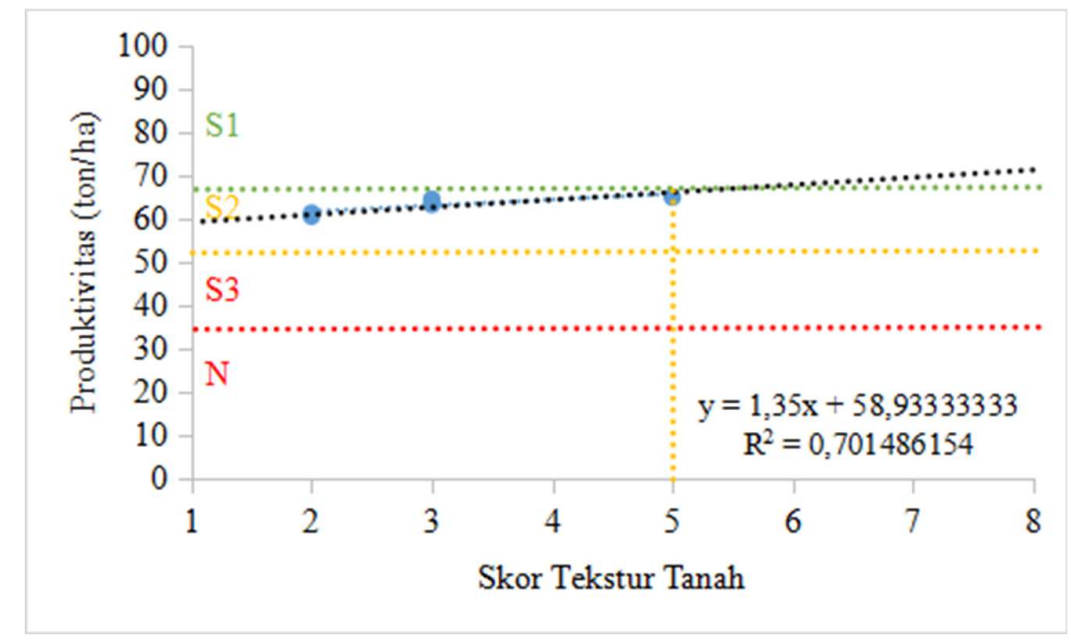

Gambar 4. Hubungan tekstur terhadap produktivitas nanas.

\section{Kriteria kesesuaian lahan untuk tanaman nanas hasil modifikasi}

Modifikasi kriteria kesesuaian lahan dilakukan terhadap karakteristik lahan yang memiliki pengaruh signifikan pada produktivitas nanas yaitu tekstur tanah. Modifikasi kriteria kesesuaian lahan dapat dilihat pada Tabel 4.

\section{Kesesuaian lahan menurut kriteria hasil modifikasi}

Kesesuaian lahan menurut hasil modifikasi boundary line analysis yaitu kelas S2 (cukup sesuai), S3 (sesuai marjinal), dan $\mathrm{N}$ (tidak sesuai). Peta Kelas Kesesuaian Lahan Menurut Hasil Analisis Boundary Line dapat dilihat pada Gambar 5.

Tabel 4. Modifikasi kriteria kesesuaian lahan.

\begin{tabular}{cccc}
\hline Karakteristik & Kelas & \multicolumn{2}{c}{ Perubahan Nilai Karakteristik Lahan } \\
\cline { 3 - 4 } Lahan & Kesesuaian & Acuan & BL \\
\hline Tekstur & S1 & halus, agak halus, sedang & halus, agak halus, sedang \\
& S2 & agak kasar & kasar, agak kasar \\
& S3 & sangat halus & sangat halus \\
& N & kasar & \\
\hline
\end{tabular}

Keterangan: acuan: kriteria kesesuaian menurut kriteria acuan Ritung et al. (2011); BL: kriteria kesesuaian hasil modifikasi berdasarkan analisis boundary line. 


\section{Jurnal Tanah dan Sumberdaya Lahan Vol 8 No 2: 515-525, 2021 e-ISSN:2549-9793, doi: 10.21776/ub.jts1.2021.008.2.22}



Gambar 5. Peta kelas kesesuaian lahan lokasi penelitian menurut hasil analisis boundary line.

\section{Upaya manajemen lahan untuk mengatasi faktor pembatas}

Hasil evaluasi kesesuaian lahan di lokasi penelitian menunjukkan bahwa terdapat tiga kelas kesesuaian lahan, yaitu kelas kesesuaian S2 (cukup sesuai), S3 (sesuai marjinal), dan N (tidak sesuai). Faktor yang menjadi pembatas di lokasi penelitian antara lain ketersediaan air (curah hujan), ketersediaan oksigen (drainase), media Perakaran (tekstur, dan kedalaman tanah), retensi hara (KTK tanah, $\mathrm{pH}$ aktual, dan COrganik), hara tersedia ( $\mathrm{N}$ tTotal, $\mathrm{P}$ tersedia, dan Kdd), serta bahaya erosi (lereng, dan bahaya erosi). Faktor pembatas curah hujan, dan drainase tidak perlu dilakukan perbaikan karena tidak terlalu beresiko tinggi terhadap pertumbuhan nanas. Faktor pembatas tekstur tidak dapat diperbaiki karena berhubungan dengan faktor alam yang tidak bisa dipengaruhi oleh manusia secara langsung. Kedalaman tanah merupakan faktor pembatas yang umumnya tidak dapat dilakukan perbaikan kecuali pada lapisan padas lunak dan tipis dengan membongkar saat melakukan pengolahan tanah yang tingkat pengolahannya tinggi dan memerlukan biaya yang sangat besar. Perbaikan faktor pembatas retensi hara meliputi KTK, $\mathrm{pH}$ tanah, dan $\mathrm{C}$ organik dapat dilakukan dengan pengapuran dan penambahan bahan organik tanah. Perbaikan faktor pembatas hara tersedia meliputi $\mathrm{P}_{2} \mathrm{O}_{5}, \quad \mathrm{~N}$ total, dan K-dd dapat dilakukan dengan pemberian pupuk yang berimbang dan tepat waktu. Perbaikan faktor pembatas bahaya erosi yang meliputi bahaya erosi aktual dan kemiringan lereng dapat dilakukan dengan penanaman tanaman penutup tanah (Rayes, 2007) dan pembuatan terasering. Menurut Jayanti et al. (2013) usaha perbaikan yang dapat dilakukan adalah dengan usaha/tindakan konservasi tanah, misalnya pengurangan erosi dengan membuat teras atau guludan, penanaman sejajar kontur, pengolahan tanah menurut kontur, dan lain sebagainya.

\section{Kesimpulan}

Kelas kesesuaian aktual berdasarkan kriteria acuan meliputi kelas S2, S3, dan N. Faktor faktor pembatas pada kelas kesesuaian tersebut yaitu ketersediaan air (curah hujan), ketersediaan oksigen (drainase), media Perakaran (tekstur, dan kedalaman tanah), retensi hara (KTK tanah, $\mathrm{pH}$ aktual, dan C-Organik), hara tersedia 


\section{Jurnal Tanah dan Sumberdaya Lahan Vol 8 No 2: 515-525, 2021 e-ISSN:2549-9793, doi: 10.21776/ub.jts1.2021.008.2.22}

( $\mathrm{N}$ ttal, $\mathrm{P}$ tersedia, dan Kdd), serta bahaya erosi (lereng, dan bahaya erosi). Karakteristik lahan yang paling mempengaruhi produktivitas nanas di lokasi penelitian yaitu tekstur tanah. Berdasarkan produktivitas tanaman nenas pada beberapa SPL, maka Kriteria kesesuaian lahan hasil modifikasi menggunakan pendekatan boundary line analysis menghasilkan perubahan pada satu karakteristik lahan yaitu tekstur tanah (S1: halus, agak halus, sedang; S2: kasar, agak kasar; S3: sangat halus).

\section{Ucapan Terima Kasih}

Penulis mengucapkan terima kasih kepada teknisi Laboratorium Pedologi dan Sistem Informasi Sumberdaya Lahan dan Laboratorium Fisika Tanah Jurusan Tanah, Fakultas Pertanian, Universitas Brawijaya, serta teknisi Laboratorium Tanah Balai Pengkajian Teknologi Pertanian Jawa Timur atas bantuannya dalam analisis sampel tanah.

\section{Daftar Pustaka}

Badan Pusat Statistik, 2019. Statistik Daerah Kabupaten Kediri 2019. BPS. Kabupaten Kediri.

Badan Pusat Statistik. 2018. Statistik Tanaman Buahbuahan dan Sayuran Tahunan. BPS. Jakarta.

Balai Penelitian Tanah. 2004. Petunjuk Teknis Pengamatan Tanah. Pusat Penelitian dan Pengembangan Tanah dan Agroklimat. Badan Penelitian dan Pengembangan Pertanian. Departemen Pertanian. Bogor.

BBSDLP (Balai Besar Penelitian dan Pengembangan Sumberdaya Lahan Pertanian). 2011. Petunjuk Teknis Evaluasi Lahan untuk Komoditas Pertanian. Edisi revisi, Badan Penelitian dan Pengembangan Pertanian Kementerian Pertanian 2011.

Cahyono, E.A., Ardian. dan Silvina, F. 2014. Pengaruh pemberian beberapa dosis pupuk NPK terhadap pertumbuhan berbagai sumber tunas tanaman nanas (Ananas comosus (L) Merr) yang ditanam antara tanaman sawit belum menghasilkan di lahan gambut. JOM Faperta 1(2): 11-16.

FAO. 1976. A Framework for Land Evaluation. Soil Resources Management and Conservation Service Land and Water Development Division. FAO Soil Bulletin No. 32. FAO-UNO, Rome.
Jayanti, D.S., Goenadi, S. dan Hadi, P. 2013. evaluasi kesesuaian lahan dan optimasi penggunaan lahan untuk pengembangan tanaman kakao (Theobroma cacao L.) (Studi kasus di Kecamatan Batee dan Kecamatan Padang Tiji Kabupaten Pidie Provinsi Aceh). Jurnal Agritech 33(2) : 208-218.

Marsoedi, D.S., Widagdo., Dai, J., Suharta, N., Darul, S.W.P., Hardjowigeno, S., Hof, J. dan Jordens, E.R. 1997. Pedoman Klasifikasi Landform. Laporan Teknis 5 Versi 3. Second LREP Project Part C. Centre for Soil and Agroclimate Research, Bogor.

Rachman, A., Dariah, A. dan Husen, E. 2004. Olah Tanah Konservasi. Teknologi Konservasi Tanah pada Lahan Kering. Puslitbangtanak. Badan Litbang Pertanian. Departemen Pertanian 2004.

Rayes, M.L. 2007. Metode Inventarisasi Sumber Daya Lahan. Penerbit Andi. Yogyakarta.

Ritung, S., Nugroho, K., Mulyani, A. dan Suryani, E. 2011. Petunjuk Teknis Evaluasi Lahan Untuk Komoditas Pertanian (Edisi Revisi). Balai Besar Penelitian dan Pengembangan Sumberdaya Lahan Pertanian, Badan Penelitian dan Pengembangan Pertanian, Bogor. $168 \mathrm{hlm}$.

Rosyidah. E, dan Wirosoedarmo, R.,2013. Pengaruh sifat fisik tanah pada konduktivitas hidrolik jenuh di 5 penggunaan lahan (Studi kasus di Kelurahan Sumbersari Malang). Jurnal Agritech 33 (3) : 340345.

Soil Survey Staff. 2014. Kunci Taksonomi Tanah. Edisi Ketiga, 2015. Balai Besar Penelitian dan Pengembangan Sumberdaya Lahan Pertanian, Badan Penelitian dan Pengembangan Pertanian.

Syekhfani. 2005. Peranan Bahan Organik Dalam Mempertahankan Kesuburan Tanah. Bagpro PKSDM Ditjen Dikti Depdiknas kerjasama dengan Fakultas Pertanian Universitas Brawijaya, Malang.

Tjasyono, B. dan Gunarsih. 2004. Arti Penting Klimatologi. ITB. Bandung.

Wahyunto, Hikmatullah., Suryani, E., Tafakresnanto, C., Ritung, S., Mulyani, A., Sukarman., Nugroho, K., Sulaeman, Y., Suparto., Subandiono, R.E., Sutriadi, T. dan Nursyamsi, D. 2016. Petunjuk Teknis Pedoman Survei dan Pemetaan Tanah Tingkat Semi Detail Skala 1:50.000. Balai Besar Penelitian dan Pengembangan Sumberdaya Lahan Pertanian, Badan Penelitian dan Pengembangan Pertanian, Bogor. 44 hal. 